\title{
The Implementation of Accrual-Based Accounting in Malaysian Public Sector: Opportunities and Challenges
}

\author{
Nur ShawallizaYusof ${ }^{\mathrm{a}}$, Hartini Jaafar ${ }^{\mathrm{b}}$ \\ ${ }^{a}$ Faculty of Management and Economics, Universiti Pendidikan Sultan Idris, Malaysia, \\ snowflakes_xyz@yahoo.com \\ ${ }^{b}$ Faculty of Management and Economics, Universiti Pendidikan Sultan Idris, Malaysia, \\ hartini@fpe.upsi.edu.my
}

\begin{abstract}
Public sector reforms in Malaysia begun in the 1980s with the primary objective of improving the effectiveness, efficiency and transparency of governmental operational and financial management. The shift from cash-based accounting to accrual-based accounting in the public sector constitutes one of the measures outlined in the New Economic Model (NEM) under this reform initiative. The aim of this paper is to examine the opportunities and challenges faced by the Malaysian public sector in implementing accrual-based accounting. A review of previous literature in this area showed that accrual-based accounting improves decision-making processes, promotes better financial management and enhances public accountability. However, the transition process between these two accounting methods is not without challenges. Human resources competency, software and technology capability, accounting policies and standards suitability are identified as major challenges in the implementation effort. These challenges should be taken into consideration carefully by the government in order to ensure successful migration towards accrual-based accounting.
\end{abstract}

\section{Keywords:}

Accrual-based cccounting, Malaysian public sector

\section{INTRODUCTION}

There are two basic recording methods in accounting which are the cash-based and accrual-based accounting method. Cash-based accounting is a method where revenue and expenses are recognised when payment is made or received. Although it is easier to record in cash-based accounting, the argument is that the income statement and balance sheet under this method do not show financial information on recent activity (Hassan, 2012). In contrast, accrual-based is a method where a transaction is recorded when the item is delivered or services occur. It is primarily argued that by using accrual-based accounting, financial statements will show the true and fair value of equity financial situation and profit and losses (Tiran Tudor \& Blidisel, 2007).Therefore, the financial information on balance sheet and income statement are more accurate because revenue is recorded when sales occur while expenses is recorded when goods or services are received (Hassan, 2012).

According to Tiran Tudor and Blidisel (2007), public sector used traditionally cashbased accounting to record the transactions occurred while accrual-based accounting is more widely known as the modern accounting system and is used mostly in private sector. Cavanagh, Flynn and Moretti (2016) found that 41 governments of the world have completed the transition from cash-based to accrual-based accounting, 16 governments accounts are a on a modified accrual basis, 28 governments are on a modified cash basis and 114 governments remain on cash-based accounting. Based on these findings, it can be seen that a majority of governments in the world are still using cash-based accounting instead of shifting to accrual- 
based accounting in their public sector. Public sector organisations prefer to choose cashbased accounting than accrual-based accounting because cash-based accounting is said to be simpler and more understandable to record (Tiran Tudor \& Blidisel, 2007). It is simpler because cash-based accounting omits fixed assets, debtors, creditors and other liabilities and even unpresented cheques at year end are omitted from the accounts (Cordery, 2010). However, cash-based accounting does not show the actual financial information needed by the external and internal users of the company. It also does not reflect the true value of public sector performance compared to accrual-based accounting (Hepworth, 2003).

Several scholars believe that the migration to accrual-based accounting is part of the process of adopting the style of financial statements practised by companies in the private sector into the public sector (Tickell, 2010; Hassan, 2012; Rozaidy, Raman, Rasid \& Kaziemah, 2014). The transformation will also provide sustainability, provide better measure of policies effect, improve organizational efficiency and effectiveness, promote greater integrity (Auditor General Report, 2014) and provide greater accountability (Murni, Norida, Azimon \& Azlina, 2014). Heeks (1998) stated that the creation of a new accounting system which is accrual-based accounting is a main component in the creation of accountability. Accountability means that some set of recipients such as the citizen receives information about outcomes of decisions made by the source decision makers such as Prime Minister and the decision makers can explain on their decisions with proves (Heeks, 1998). For instance, the Minister may be held accountable by the public for corrupt activities within their ministry. It is claimed that the use of accrual-based accounting may reduce corruptions since all the financial information are included in financial statements (Heeks, 1998).

Malaysian public sector is structured into a three-tier government which are the federal government, state government and local government including city councils, municipal councils and district councils (Fatimah, Haslinda, Normahiran, Usha Rani, Saluana \& Radiah, 2015). The Malaysian federal government has been using cash-based accounting since independence and adopted the modified cash-based accounting in 1974 (Saleh, Isa, \& Hasan, 2012). However, expansion in economic activities, combined with limited resources and increased public scrutiny has motivated the Malaysian government to migrate to accrualbased accounting. It is generally argued that accrual-based accounting plays an important role in enhancing public accountability and promoting better public financial management and good governance. This move nonetheless, is not without its challenges. Therefore, this study aims to review the opportunities and challenges associated with Malaysian government decision to transition from cash-based to accrual-based accounting system.

\section{THE MOVE TOWARDS ACCRUAL-BASED ACCOUNTING: MALAYSIAN EXPERIENCE}

The initiatives towards achieving a developed and high-income nation status were undertaken by the Malaysian government beginning in 2010 (Ruhaya \& Faziyatun, 2015). Such intitiaves require mainly major public sector structural reforms and in May 2011, the Malaysian government announced its plan to implement accrual-based accounting in the public sector (Muhammad Iqbal, 2013). Accrual-based accounting in public sector is listed as one of the key policy measures in Malaysia NEM in an effort to improve public sector finance practices. The decision to move from cash-based accounting to accrual-based accounting is triggered largely by the growing demand for a greater transparency and better performances of the government sector and the companies controlled by the government (Ropidah, Noor Afza \& Norhani, 2005). According to Bontas and Petre (2009), accrual-based accounting 
provides information on financial position and current assets and liabilities in balance sheet. This information is important in managing their cash position and financing requirements. Besides, accrual-based accounting also facilitates in managing resources through income statement which is more useful than cash-based accounting because performance can be measured more reliably when full costs for a certain period are taken into account. It also provides non-cash information such as revaluations, consumption of assets through depreciation and pension liabilities. Thus it will provide greater transparency since more financial information are included when recorded using accrual-based accounting method.

Further, the International Federation of Accountants (IFAC) in November 2013 have drawn a transition plan (2015 - 2019) based on International Monetary Fund recommendations in which revenue from taxes will be recognized on accrual-based accounting. The transition plan of the implementation of accrual-based accounting is as shown in Figure 1.

Figure 1: Accrual-based accounting transition plan of public sector in Malaysia

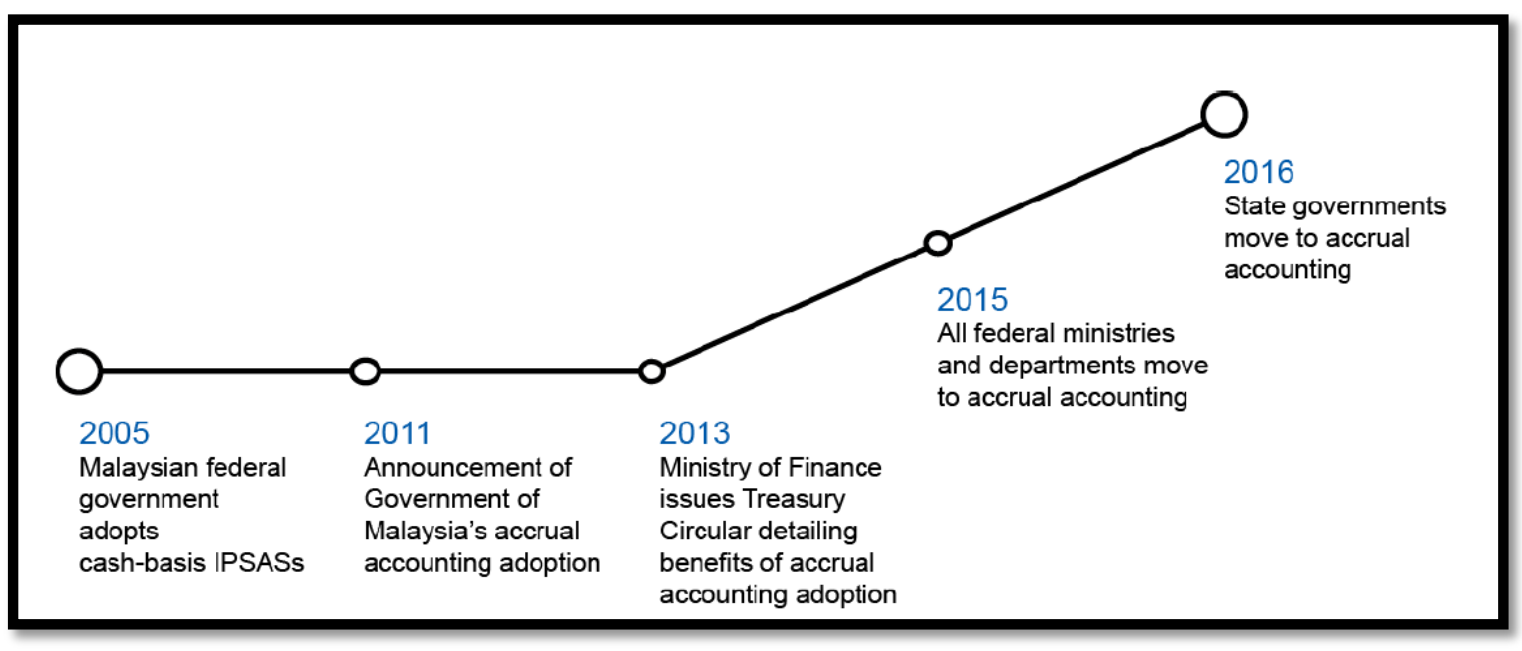

Source: International Federation of Accountants (IFAC)-A Closer Look at: Malaysia (2013)

However, up until 2014 the transition to accrual-based accounting has been delayed and at present both federal and state governments are still using the modified cash basis accounting. The modified cash basis is based on the International Public Sector Accounting Standards (IPSAS) that have been revised in 2006. Modified cash basis comply with the cash basis of IPSAS standards where assets are not capitalised and liabilities are recorded outside the accounting system. However, the limited time frame given posed challenges for the government to implement accrual-based accounting. Up to this date, it has been almost eight years since the process of implementation of full accrual-based accounting in public sector in Malaysia begun in 2011. However, in the recently tabled Malaysia Budget 2019, the newly elected government has proposed some institutional reform initiatives to make institutions clean and people-centric, including once again, the use of accrual basis of accounting to replace the modified cash basis accounting. This means that after a few false starts since 2014, accrual accounting will be a fait accompli by 2021 (Xavier, 2018)

Compared to the previous experiences from other countries, the period given by the Malaysian government is shorter which means there is a limited time for the public sector to be fully prepared to implement accrual-based accounting. Within this short period of time, the government has faced many challenges, in terms of creating awareness about accrual-based 
accounting and actions taken to reform the legislative and regulatory structure (Malaysian Institute of Accountants, 2011). In addition, the public sector also needs to integrate a new system and improve the skills and knowledge of human resource in implementing accrualbased accounting. In doing so, the government has provided training and has undeniably spent a huge amount of financial resources (Rozaidy et al., 2014). According to the transition plan, the accounting system will follow the Malaysia Public Sector Accounting Standards (MPSAS) which is drawn primarily from IPSAS with some minor changes in order to accommodate the national circumstances. The decision to follow international standards is to ensure that the financial information provided are comparative across countries.

Table 1: MPSAS approved by Accrual Accounting Steering Committee

\begin{tabular}{|c|c|}
\hline MPSAS & Content \\
\hline MPSAS 1 & Presentation of Financial Statement \\
\hline MPSAS 2 & Cash Flow Statements \\
\hline MPSAS 3 & Accounting Policies, Changes in Accounting Estimates and Errors \\
\hline MPSAS 4 & The Effect of Changes in Foreign Exchange Rate \\
\hline MPSAS 5 & Borrowing Costs \\
\hline MPSAS 6 & Consolidated and Separate Financial Statements \\
\hline MPSAS 7 & Investments in Associates \\
\hline MPSAS 8 & Interests in Joint Ventures \\
\hline MPSAS 9 & Revenue From Exchange Transactions \\
\hline MPSAS 11 & Construction Contracts \\
\hline MPSAS 12 & Inventories \\
\hline MPSAS 13 & Leases \\
\hline MPSAS 14 & Events After the Reporting Date \\
\hline MPSAS 16 & Investment Property \\
\hline MPSAS 17 & Property, Plant and Equipment \\
\hline MPSAS 19 & Provisions, Contingent Liabilities and Contingent Assets \\
\hline MPSAS 20 & Related Party Disclosure \\
\hline MPSAS 21 & Impairment of Non-Cash-Generating Assets \\
\hline MPSAS 22 & Disclosure of Financial Information \\
\hline MPSAS 23 & Revenue From Non-Exchange Transactions (Taxes \& Transfers) \\
\hline MPSAS 24 & Presentation of Budget Information in Financial Statement \\
\hline MPSAS 25 & Employee Benefits \\
\hline MPSAS 26 & Impairment of Cash-generating Assets \\
\hline MPSAS 27 & Agriculture \\
\hline MPSAS 28 & Financial Instruments: Presentation \\
\hline MPSAS 29 & Financial Instruments: Recognition and Measurement \\
\hline MPSAS 30 & Financial Instruments: Disclosure \\
\hline MPSAS 31 & Intangible Assets \\
\hline MPSAS 32 & Service Concession Arrangements: Grantor \\
\hline MPSAS 33 & First-Time Adoption of Accrual Basis MPSASs \\
\hline MPSAS 34 & Separate Financial Statements \\
\hline MPSAS 35 & Consolidated Financial Statements \\
\hline MPSAS 36 & Investments in Associated and Joint Ventures \\
\hline MPSAS 37 & Joint Arrangements \\
\hline MPSAS 38 & Disclosure of Interest in Other Entities \\
\hline
\end{tabular}

Source: Accountant General's Department of Malaysia

(http://www2.anm.gov.my/akruan/Pages/Polisi-dan-Piawaian.aspx) 
Table 1 shows the MPSAS that have been approved by the Accrual Accounting Steering Committee (as of October 2018). According to the accrual accounting initiatives, the opening balances of assets and liabilities will be taken in progressively from 2015 to 2019. This process had forced the accountants involved in governmental financial reporting to develop proper strategies to ensure successful implementation of accrual-based accounting in the public sector.

\section{THE PRESUMED BENEFITS OF ACCRUAL-BASED ACCOUNTING IN PUBLIC SECTOR}

There is increasing public interest on the performance of Malaysian public sector especially in the aspects of education, health and public services. The public has moved from a passive service recipient to demand for greater transparency and accountabilities for public sector performance and management (Tooley, Hooks \& Norida, 2009). However, the main problem faced by the public and other users such as investors or stakeholders is that they could not make adequate and informed judgement on the performance of Malaysian government. This is largely due to them being unable to access the true cost of the services provided as well as the quantity and quality of the services. Taking this issue into consideration, the implementation of accrual-based accounting is viewed as one of the best ways in helping the users to evaluate the entity's performance by presenting the true cost of the services through financial reporting. Hence, this transformation will provide the full cost of services, provide better financial reporting and reflect the true picture of the fiscal position of the government (Saleh \& Pendlebury, 2006).

The main objective of the implementation of accrual-based accounting in Malaysian public sector is to have better transparency and greater accountability (Wan Selamah, 2013). Accounting standards for accrual-based accounting set by IPSAS promote openness and access to information by citizens and their understanding on decision-making mechanisms (Ijeoman, 2014). Therefore, the decision making will be more transparent and corruption can be reduced. According to the Corruption Perception Index in 2015 (Deinert, 2015), Malaysia is ranked at 54 from 175 countries in the world with a score corruption of 50 which means that the level of corruption in Malaysia is moderate. Therefore, it can be argued that one of the reasons for Malaysian government to implement accrual-based accounting in the public sector is to seek for greater transparency and also to reduce the level of corruption in Malaysian public sector.

Besides, accrual-based accounting is to be implemented in Malaysian public sector as it can determine the full cost of the whole government activities including non-cash costs and non-debt liabilities such as depreciation and pension obligations. According to Khan and Meyes (2009), the full cost information will help the government to identify assets and liabilities in the public sector. Thus, it will improve public sector performance and the government can then provide a better financial planning since they have a complete information regarding the cost of government activities including assets and liabilities. According to the then Accountant General, costing data enables more effective evaluation of alternatives in achieving better decision making besides lead to a better management of asset and liabilities (Wan Selamah, 2011). According to Xavier (2018) the IMF found that governments that use accrual accounting have lower debts, smaller deficits and better bond yields than tose with other accounting systems. This is primarly because as accrual accounting allows the public to dig deeper into its ledgers, the government will invariably face greater pressure to pare down the debt and deficit. 
Another reason that urge the government to implement accrual-based accounting in Malaysian public sector is the quality of the information that helps in improving decision making process (Nurul Nadiah, Santer Nurfarahinas, Saiyidah Diyana \& Muhamad Hadi Zulfadli, 2015). Accrual-based accounting will show the financial position of Malaysian public sector and its current assets and liabilities. Therefore, the information will help the public sector to make decisions regarding the financing of the service provided by the public sector. Moreover, the implementation of accrual-based accounting has been established as one of the policy measures in the NEM as a means to improve decision making processes and strengthen public finance management of Malaysian public sector (Raja Abdullah\& Nik Mustapha, 2010).

In addition to that, Rodan (2000) found that the Asian economic crisis in 1998 has increased the tendency of the government such as Singapore and Malaysia to have a better transparency and accountability system. Greater transparency will give a good perception to the investors about the system in a country. The increase of investor confidence will in turn contribute to the growth of economy. Therefore, it is important for Malaysia to have a good accounting system to improve transparency and accountability hence, attract foreign investments to stimulate economic growth. In general, the move to accrual-based accounting will help the government to provide a better cost information that helps to increase transparency, improve decision making and consequently provide a better performance of Malaysian public sector.

\section{ACCRUAL-BASED ACCOUNTING IMPLEMENTATION: ISSUES AND CHALLENGES}

The migration from cash-based accounting to accrual-based accounting in the public sector has been an interchanging debate and widely discussed. Some of the developed countries such as the United Kingdom (UK), Australia and New Zealand have obtained the benefits of the accrual-based accounting in many sections especially in terms of public sector financial reporting (Connolly \& Hyndman, 2006). These countries generally adopt accrualbased accounting in their public sector due to perceived benefits of accrual-based accounting system such as increase in budget transparency and government efficiency through performance-based management (Champoux, 2006). Thus, it will provide more reliable and accurate financial information that can be used in making financial decisions.

However, one of the primary challenges in its implementation is the length of the whole process before the benefits of accrual-based accounting can be realised. For instance, according to the UK National Audit Office in 1993, the benefits of accrual-based accounting cannot be identified at the preliminary stage of the implementation. The UK government need to overcome many obstacles in order to gain its benefits and it took several years to complete the transformations. According to Wynne (2007) a survey conducted in the UK public sector revealed that majority of the public servants (63\%) disagree with changes to accrual-based accounting. They viewed that the process of changing from cash-based accounting to accrualbased accounting seemed to be unnecessary mainly due to uncertainty of risks that the government is unable to assess.

The IFAC Public Sector Committee has set the task of developing a full set of international public sector accounting standards which includes recognition of asset and liabilities (IFAC, 2011). The Committee has also developed accounting standard on financial reporting using accrual-based accounting and ensuring that these are adopted as widely as 
possible. Many countries are interested in implementing accrual-based accounting because it is claimed that accrual-based accounting in public sector will bring more advantages (Hassan, 2012). Wynne (2007) argued that the presumed advantages of accrual-based accounting are; (1) it provides more comprehensive financial information, (2) it allows better management of assets and (3) it can provide the full cost of public services. Comprehensive financial information will help in making financial decisions for the country so as to have a better fiscal position. According to Ian Ball, the Chairman of International Chartered Institute of Public Finance and Accountancy, a good accounting system will help the government to achieve better fiscal decisions and give a better position in the future (Care, 2016).

However, several scholars such as Ouda (2004), Rowles (2004), Khan and Meyes (2009) argued that accrual-based accounting is not suitable to be implemented in the public sector because the nature of its economic reasoning is totally different from the private sector. For example, the government has certain types of assets and liabilities that do not exist in the private sector. Public assets such as heritage- type assets and environmental assets are known as 'public' goods (Ouda, 2004) and full accrual-based accounting are irrelevant to the assessment of the efficiency of 'core' public sector activities since the performance measurement is different (Rowles, 2004). According to IPSAS17, heritage assets refers to an asset that has cultural, environmental and historical interests, for example historical building, monument, archaeological site and artifact while environmental assets refer to living and nonliving resources such as mineral resources. Previous scholars have argued that these types of specialised public assets do not match the definition of assets in accrual accounting (Norida, Mohd Fairuz, Azlina, Azizah \& Ismail, 2015). Similarly, Christiaens et al. (2012) stated that capital assets with attributes similar to those of public goods such as heritage assets and environmental assets, should not be capitalised and included in the statement of financial position. These arguments with regards to recognition extend to other accounting treatments for public goods including measurement, valuation and disposal of such assets.

Besides, the government also needs to make selection on the appropriate accounting policies that are relevant to the local accounting standards that suit the national circumstances. It is argued that accounting system and budgeting system need to be closely aligned to provide good financial information (Khan \& Meyes, 2009). Additionally, the obstacles of implementing accrual-based accounting can only be noticed after the accrual-based accounting policy has been successfully implemented in OECD countries such as Australia and Canada (Khan \& Meyes, 2009). Overall, despite all the benefits, Wynne (2008) also found that the process of shifting from the old system to accrual-based accounting in the public sector involve a very high cost of implementation.

In Malaysia, the idea to implement accrual-based accounting in the public sector has begun in the year 2000 due to deemed benefits to be derived from the implementation of accrual-based accounting in the public sector. Besides providing better financial management and more accurate information for decision making process, accrual-based accounting can also improve assets management (Nurul NadiahAhmad et al., 2015). In order to make sure the implementation of accrual-based accounting is successful, there are many aspects that need to be considered including the high implementation cost. Gomes (2013) stated that customisation was necessary in the accrual-based accounting because different countries possess different socio-economic and political environments. Some of the issues involved changes of accounting policies and standards, new technology and human resources. Similarly, the International Public Sector Accounting Standards Board (IPSASB) has identified three main aspects that are crucial in the implementation of accrual-based 
accounting in public sector, which are accounting policies and standards, software and technology and human resources (IPSASB, 2015). These important aspects need to be emphasized by the government to ensure that the implementation of accrual-based accounting in Malaysian public sector is successful. Previous research found that countries that implement accrual-based accounting experience longer adoption time than what was initially expected (Muhammad Iqbal, 2013). For example, countries such as New Zealand, Sweden and the UK took more than 10 years in order to fully gain the benefits (Connolly \& Hyndman, 2005).

Based on the experiences of these countries, this suggests that there are many challenges and obstacles that need to be overcome in the process of implementation. In addition, many aspects need to be considered for successful implementation which requires careful and high level strategy of implementation. For instance, they need to reformulate accounting policies suitable to the country itself primarily with respect to the valuation of assets and liabilities of public sector. Besides, they also need to make sure that the financial information provided from the new accounting system fulfil the information needed by the whole government. Blondal (2003) identified the issues that arise in adopting accrual-based accounting in public sector. In the study, the researcher focused on culture change in public sector which includes the need for communication system, accountancy skills and selection of software system. By contrast, Wynne (2007) stated that the willingness of public sector employees to accept the transformation of accounting practice would first require comprehensive training that involved the whole organization including lower ranked staff. It is the most important pre-condition to implement accrual-based accounting in public sector.

Muhammad Iqbal (2013) found that there are still many government servants in Malaysia with limited knowledge in the accrual-based accounting. Although the management had already provided training and seminar for them, these employees are still unwilling to participate. Therefore, the management and also the government should provide more initiatives to attract the employees. Another reason why Malaysian public sector did not manage to fully implement accrual-based accounting until today is because of the inadequacy in the readiness of accounting information system applications such as equipment, software customization and systems familiarization (Rozaidy et al., 2014).

\section{Human resources}

Training for human resources is the key element of the success of any project and especially in the implementation of accrual-based accounting in public sector (Mohammadi, Mohammadi \& Zare, 2012). According to Khan and Mayes (2009), lack of skilled technical resources is one of the major obstacles for successful implementation of accrual-based accounting. The government need to consider hiring outside consultant to develop systems that suit the national circumstances. In order to reduce the gap between the capabilities of existing staff, the government need to recruit staff from the private sector, the development of university and seminars and workshops by external auditor entities (IPSASB, 2011).

Nik Zam Nik Wan (2005) stated that staff resistance in moving towards accrual-based accounting made them resist to undergo the training programs being organized. Staff were unable to see the benefits of the implementation of accrual-based accounting in Malaysian public sector. In addition, the researcher also found that the government need to provide training for the staff to make sure they are competent with accrual-based accounting system. They need to prepare themselves with knowledge and skills in the accrual-based accounting 
system. In addition, the senior staff also were facing problems in using the computer for the new system of accrual-based accounting. Nik Zam Nik Wan (2005) also argued that the accountants in the government sector were not recognised as the expertise or specialist. Therefore, allocation of fund is needed to organize a training program.

Fauziah and Noor Azman (2014) investigated the perceptions, acceptance and capabilities of the clients and employees involved in the process of implementation of accrual-based accounting in Malaysian public sector. The findings showed that employee capability was the highest concern compared to employee perception and acceptance. Apart from that, the finding from the multiple regression also suggested that the government need to consider employee acceptance to make sure the implementation of accrual-based accounting more successful. Therefore, there is a need for the government to overcome people's resistance in moving to accrual-based accounting.

\section{Software and technology}

The implementation of accrual-based accounting involves changes a wide range of information systems. Wynne (2003) explained that the Information Technology (IT) capacity of a country must be able to respond the additional requirement in the implementation of accrual-based accounting in public sector. In addition, the transition to accrual-based system not only require financial resources but also in terms of specialist IT skills. The government need to consider redesigning the system to make sure it support accrual-based accounting (IPSASB, 2011).

Tickell (2010) investigated the migration to accrual-based accounting in Fiji and discovered that most respondents stated that the software purchased by the government was too complex, expensive and require a lot of system changes. Therefore, the respondents believed that purchasing the appropriate software and IT facilities is important. The author concluded that the first attempt in implementation of accrual-based accounting in the Fiji public sector failed due to software problem.In addition, Sturesson et al. (2013) found that almost half of the respondents identified IT system requirement as one of top three challenges in implementing accrual-based accounting in public sector. Adequate IT system is needed in recording and reporting data using accrual-based accounting. For instance, IT capabilities are needed to add details of good and services received in the expense workflow and also to communicate financial information to users. Apart from that, technical IT and enterprise resource planning (ERP) expertise are also needed to make sure the government have a good internal control system. The IT system has also become an obstacle in adopting the IPSAS standard or other accounting standard that meet the new accounting system.

Similarly, Azrina Hani Azmi and Nafsiah Mohamed (2014) explored the readiness of Malaysian public sector employee in moving towards accrual-based accounting for improving accountability. The findings showed that respondents are ready to move to accrual-based accounting but there were few challenges that were perceived to occur. One of them is regarding the new IT system. The integration of current accounting system with the new accounting system may be difficult due to insufficient capacity and availability of subsystems and functionalities required. 


\section{Accounting policies and standards}

The Organizations for Economic Co-operation and Development (OECD) (1993) stated that specific accounting policies and standards need to be developed for the implementation of accrual-based accounting in the public sector. Due to the differences between public sector and private sector, some issues arise in applying the accounting standards. The issues that had been common to all countries is the valuation of assets and liabilities for asset that only have in the public sector such as heritage assets, pension obligations and infrastructure assets. Wynne (2003) explained that accounting policies and standards that need to be considered before the implementation include the recognition of tax revenue, the valuation of military assets, infrastructure assets, and natural resources. Besides, the government need to convert to accrual-based IPSAS or equivalent standards to make sure the financial information using accrual-based accounting can bring usefulness to the intended users (Sturesson et al., 2013). Although IPSAS standards bring a lot of advantages, it become one of the challenges for the government where they need to reformulate the accounting policies and standard that compliance with IPSAS. In addition to that, the implementation of the accounting standards are time and money consuming (Biraud, 2010).

In Malaysia, MPSAS has been designed to follow the international accounting standards and also to suit the national circumstances. However, there are some standards that are not listed by the International Financial Reporting Standards (IFRS) that have been formulated to accommodate the needs of the public sector. According to Accountant General's Department of Malaysia (2016), MPSAS will take effect from 1 January 2017. Besides that, presentation of financial reporting according to MPSAS should have three characteristics which are complete, neutral and free from error. In addition, Accountant General's Department of Malaysia (2016) stated that there are few challenges in collecting data for the implementation of MPSAS, which are regarding data availability and completeness as well as measurement and valuation of assets. For example, failure in collecting data for opening balance in 2017 will cause incorrect amount of opening balance in time for the transitional period. Therefore, financial reporting in 2017 would face some problem because of incorrect amount in opening balance.

\section{CONCLUSION}

The transition from the current practice to accrual-based accounting in public sector in Malaysia is expected to provide more efficient and effective fiscal management and better government financial reporting. This will subsequently lead to increased transparency and accountability. The implementation initiatives undertaken by the Malaysian government so far shows that there will be a major change of accounting practice in the Malaysian public entities. The process had forced the accountants of governmental financial reporting to develop the strategies to ensure successful implementation of accrual-based accounting in the public sector. From all of the prior research, it can be concluded that accrual-based accounting provides a multitude of benefits but it may take more time to be successfully implemented and there are aspects to be considered to ensure smooth transition plan is in place. Based on the experiences of countries that have adopted the accrual-based accounting system in their public sector before, this shift to the new accounting regime will bring forth various challenges. Thus, significant consideration needs to be given to areas such as competency of human resources, availability and adequacy of technology and relevant software and changes 
to existing accounting policies and standards to ensure successful implementation of accrualbased accounting.

\section{References}

Accountant's General Department of Malaysia (2016). Preface to Malaysian Public Sector Accounting Standard. Malaysia (MPSAS). Retrieved from http://www2.anm.gov.my/akruan/Pages/aspx

Auditor General Report (October, 2014). Financial reporting system in the public service: Malaysian experience. Presented at CAPAM's Biennial Conference 2014, Putrajaya, Malaysia.

Azrina, H. A. \& Nafsiah, M. (2014). Readiness of Malaysian public sector employees in moving towards accrual accounting for improve accountability: The case of Ministry of Education (MOE). Procedia - Social and Behavioral Sciences, 164, 106 - 111.

Biraud, G. (2010). Preparedness of United Nations system organizations for the International Public Sector Accounting Standards (IPSAS). Geneva: Joint Inspection Unit.

Blondal, J. R. (2003). Accrual accounting and budgeting: Key issues and recent development. OECD Journal on Budgeting, 3 (1), 43-59.

Bontas, C. A \& Petre, M. C. (2009). Arguments for introducing accrual-based accounting in the Public Sector. Constantine Brancoveanu University, Romania.

Care, L. (2016). Auditor General Report, May 2011, 98-108.

Cavanagh, J., Flynn S., \& Moretti, D. (2016). Accrual accounting in the public sector. CESifo DICE Report, 5(3), 43-45

Champoux, M. (2006). Accrual accounting in New Zealand and Australia: Issues and solutions (Briefing Paper No. 27). Federal Budget Policy Seminar. Harvard Law School, Cambridge, Massachusetts.

Christiaens, J., Rommel, J. Barton, A. \& Everaert, P. (2012). Should all capital goods of governments be recognized as assets in financial accounting? Baltic Journal of Management, 7 (4), 429 - 443.

Connolly, C. J., \& Hyndman, N. S. (2005). The impact of resource accounting and budgeting in the Northern Ireland public sector. Association of Chartered Certified Accountants' Research Report (No 87). Certified Accountants Educational Trust, London.

Connolly, C., \& Hyndman, N. (2006). The actual implementation of accruals accounting: caveats from a case within the UK public sector. Accounting, Auditing \& Accountability Journal, 19(2), 272-290.

Cordery, C. (2010, December). Cash-based vs accrual accounting: How should NFPs account for their business?. Chartered Accountant Journal, 58-59.

Deinert, K. (2015). Corruptions Perceptions Index 2015. Transparency International. Retrieved from https://www.transparency.org/cpi2015 
Fatimah, A. R., Haslinda, Y., Normahiran, Y., Usha Rani, Saluana, C.S. \& Radiah, O. (2015). Public sector accounting: Malaysian context. Kuala Lumpur: Pearson Malaysia Sdn Bhd.

Fauziah, M. \& Noor Azman, A. (2014). Human perspective on cash to accrual-based accounting system in Malaysia. Global Review of Accounting and Finance, 5 (2), 1 15.

Gomes, M. (2013, January). Improving public sector finance. Accountants Today, 12-15.

Hassan, M. (2012). Debates on accrual accounting in the public sector: a discrepancy between practitioners and academicians. Graduate School of Economics, Nagoya University.

Heeks, R. (1998). Information systems and public sector accountability (Working Paper No. 1). Retrieved from http://www.man.ac.uk/idpm/idpm_dp.htm\#isps_wp

Hepworth, N. (2003). Preconditions for successful implementation of accrual accounting in central government. Public Money \& Management, 23 (1), 37-43.

Ijeoman, N. B. (2014). The impact of International Public Sector Accounting Standard (IPSAS) on reliability, credibility and integrity of financial reporting in state government administration in Nigeria. International Journal of Technology Enhancements and Emerging Engineering Research, 2 (3), 1-8.

International Federation of Accountants (IFAC) (2011). Handbook of international public sector accounting pronouncements. Retrieved from https://www.ifac.org/publicationsresources/2011-handbook-international-public-sector-accounting-pronouncements

International Public Sector Accounting Standards Board (2011, January). Study 14: Transition to the accrual basis of accounting: Guidance for public sector entities. New York: International Federation of Accountants.

Khan, A. \& Mayes, S. (2009, September). Transition to accrual accounting. International Monetary Fund. Retrieved from https://www.imf.org/external/pubs/ft/tnm/2009/tnm0902.pdf

Malaysian Institute of Accountant (2011). Accrual accounting the way forward. Accountants Today, 24 (6), 7-16.

Mohammadi, S., Mohammadi, M., \& Zare, S. (2012). Implementation of full accrual basis in governmental organizations (Case Study: Shiraz University of Technology, Iran). Interdisciplinary Journal of Contemporary Research in Business, 4 (2), 287- 298.

Muhammad Iqbal M. A. (2013). The preparedness of the accountant from the Malaysian accountant general's department in moving toward accrual accounting. University Teknologi Mara. Kuala Lumpur.

Murni, S., Norida, H., Azimon, A.A.\& Azlina, A. (2014). Enhancing Malaysian federal government accountability through annual report: a stakeholder perspective. International Journal of Business, Economics and Law, 4 (2), 42-50.

Nik Zam N, W. (2005). The major impacts of change from cash to accrual accounting in the public sectors. Gading Business and Management Journal, 9 (2), 49-65. 
Norida, B., Mohd Fairuz. M.S., Azlina, A., Azizah, M.H. \& Ismail, U. (2015). Challenges in accounting for heritage assets and the way forward: Towards implementing accrual accounting in Malaysia. GEOGRAFIA Malaysian Journal of Society and Space, 11 (1), $63-73$.

Nurul Nadiah, A., Santer Nurfarahinas, M., Saiyidah Diyana, A. \& Muhamad Hadi Zulfadli, P. (2015). The rationale for accrual accounting: A case of Malaysian accountant general's department. Malaysian Journal of Research, 1 (1), 20-27.

Organizations for Economic Co-operation and Development (OECD) (1993). Accounting for what? The value of accrual accounting to the public sector. Paris: OECD Publication Service.

Ouda, H. (2004). Basic requirements model for successful implementation of accrual accounting in the public sector. Public Fund Digest, 4 (1), 78-99.

Raja Abdullah \& Nik Mustapha (2010). New Economic Model (NEM): An analytical perspective. Presented at Persidangan Perkhidmatan Awam ke-15, Kuala Lumpur.

Rodan, G. (February, 2000). Transparency, Asian economic crisis and the prospects of media liberalisation. Transparency and the Global Political Economy. University of Warwick.

Ropidah O., Noor Afza \& Norhani, A. (2005) Adoption of accrual accounting in local authorities of Kedah Darul Aman. Universiti Utara Malaysia, Sintok.

Rowles, T. (2004). Accrual accounting in the public sector: Its usefulness in economic decision making. Journal of Finance and Management in Public Services, 3 (2), 63 77.

Rozaidy, M., Raman, N., Rasid, M. \& Kaziemah, S. (2014). Accrual Accounting in Malaysia: What We Should Learn from Others. Malaysian Journal of Business and Economics, 1 (2), $63-76$.

Ruhaya, A. \& Faziyatun, M.Y. (2015). Accrual accounting change: Malaysian public sector readiness. Journal of Management Research, 7 (2), 459 - 467.

Saleh, Z., \& Pendlebury, M. W. (2006). Accruals Accounting in Government - Developments in Malaysia. Asia Pacific Business Review, 12(4), 421-435.

Saleh, Z., Isa, C. R., \& Hasan, H. A. (2012). Accrual accounting: Change and managing change. IPN Journal of Research and Practice in Public Sector Accounting and Management, 2(Special Issue), 41-52.

Sturesson, J., Rouvet, J.L., Schumesch, P., \& Duval, J.P. (2013). Towards a new era in government accounting and reporting. $P w C$ Global Survey on Accounting and Reporting by Central Governments, (April), 1-44.

Tickell, G. (2010). Cash to accrual accounting: One nation's dilemma. International Business \& Economics Research Journal, 9 (11), 71-78. 
Tooley, S., Hooks, J. \& Norida Basnan (2009). Performance reporting by Malaysian local authorities: identifying stakeholder needs. Financial Accountability and Management, 26 (2), 103-133.

Tiran Tudor, A. \& Blidisel, R. (2007). Romanian accrual accounting experience in public higher education sector. Journal of Business Research, 8 (19), 121-131.

Xavier, J.A. (2018, November 8). 2019 budget: It merits our favour. New Straits Times, p. 1. Retrieved from https://www.nst.com.my/opinion/columnists/2018/11/429258/2019budget-it-merits-our-favour

Wan Selamah Wan Sulaiman (2011). Accountants today. Accountant General's Department of Malaysia, 1-8.

Wan Selamah Wan Sulaiman (2013). Transitioning to a new public sector accounting landscape - Current status and the way forward. Presented at Inaugural Treasury Economic Forum 2013, Kuala Lumpur

Wynne, A. (2003). Do private sector financial statements provide a suitable model for public sector accounts? Presented at European Group of Public Administration, Oeiras, Portugal.

Wynne, A. (2007). Is the move to accrual-based accounting a real priority for public sector accounting? Public Fund Digest, 6 (1), 25-39.

Wynne, A. (2008). Accrual Accounting for the Public Sector - A Fad That Had Its Day? International Journal on Governmental Financial Management, 17 (2), 118 - 121. 